\title{
Vulvar Hemangioma in One Year Old Baby
}

\author{
Khadija Elboukhari*, Sara Elloudi, Ibtissam Assenhaji and Fatima Zahra Mernissi
}

Department of Dermatology, University hospital of Fez, Morocco

Submission: April 21, 2020; Published: June 11, 2020

*Corresponding author: Khadija Elboukhari, Department of Dermatology, University hospital of Fez, Morocco

Keywords: Vulva ; Hemangioma ; Dermoscopy

\section{Vulvar Hemangioma}

Hemangioma is a benign tumor that can affect any site on the body, including the vulva. Our patient is a one-year-old baby, with a history of angiomatous vulva papule, which appeared since the age of one month, and increasing in size, itching and bleeding at times which encouraged the mother of the baby to come to our service. During the clinical examination, we found an angiomatous tumor of the large right lip, with a partially ulcerated surface (Figure 1). There was no increase in local temperature or increase in volume during the crying, which eliminated a vascular malformation. The dermoscope helped us a lot in retaining the diagnosis of hemangioma by showing lagunes separated by fibrotic septa (Figure 2).

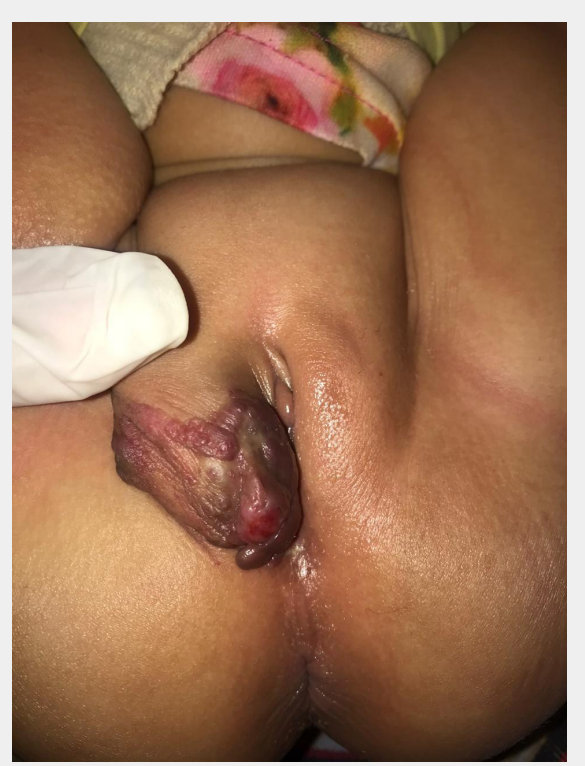

Figure 1: Angiomatous mass of the right major labia. 


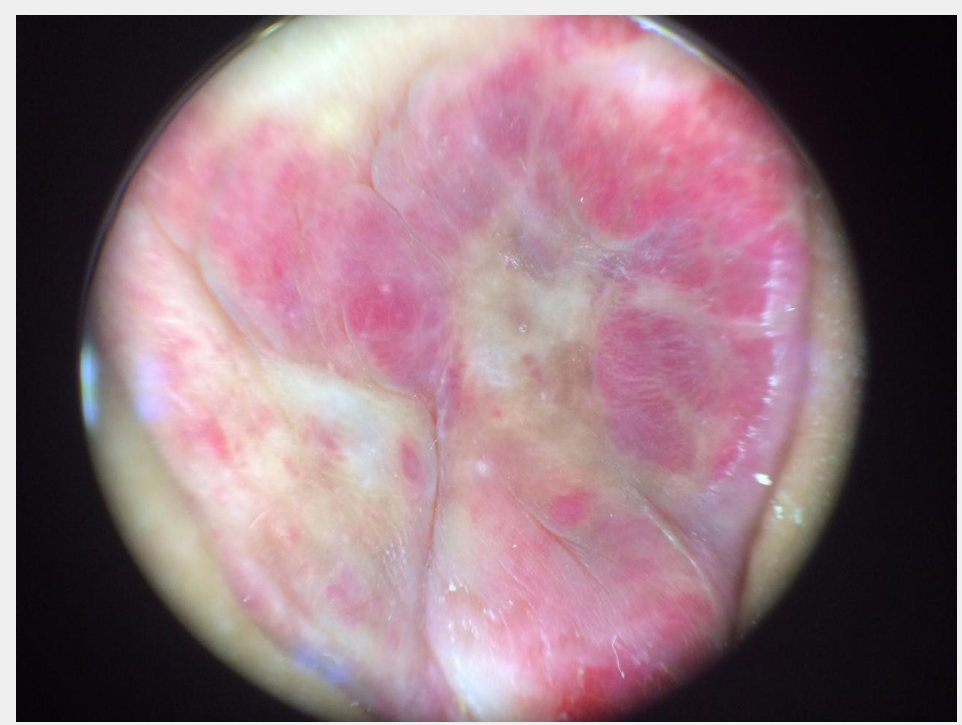

Figure 2: Dermoscopy showing vascular lagunes separated with fibrotics.

\section{Author's Contribution}

All the authors contributed to the conduct of this work. All authors also state that they have read and approved the final version of the manuscript.

\section{Acknowledgement}

We are indebted to the patient's parents for giving us the consent for the publication.

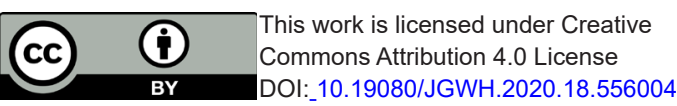

\section{Your next submission with Juniper Publishers will reach you the below assets}

- Quality Editorial service

- Swift Peer Review

- Reprints availability

- E-prints Service

- Manuscript Podcast for convenient understanding

- Global attainment for your research

- Manuscript accessibility in different formats ( Pdf, E-pub, Full Tsext, Audio)

- Unceasing customer service

Track the below URL for one-step submission https://juniperpublishers.com/online-submission.php 